In this issue

Long-Term Remission after 1 Course of 12 Weeks of Alefacept Therapy - A Case Report . . . . . . . . . . 165

Treatment of Generalized Granuloma annulare with Hydroxychloroquine . . . . . . . . . . . . . 167

Erythema multiforme Induced by Fluconazole . . . . . . 169

The Role of Hepatitis C Virus Infection in Patients with

Chronic Generalized Pruritus . . . . . . . . . . . 170

Hair Repigmentation in a Hepatitis C Patient Treated with Interferon and Ribavirin . . . . . . . . . . 171

Dermatology 2005;211:165-166

DOI: $10.1159 / 000086451$

\section{Long-Term Remission after 1 Course of 12 Weeks of Alefacept Therapy - A Case Report}

Lilla Vitéz, Elisabeth Heese, Gottfried Wozel

Department of Dermatology, University Hospital Carl Gustav

Carus, Technical University Dresden, Dresden, Germany

Key Words

Alefacept • Biologic agents · Immunomodulation •

Psoriasis $\cdot$ Systemic therapy

\section{Introduction}

Alefacept is a recombinant human leukocyte function antigen (LFA) 3/immunoglobulin G1 fusion protein that is being designed to prevent the interaction between LFA-3 and CD2 [1]. Additionally, the protein is able to induce apoptosis in critical subgroups of $\mathrm{T}$ cells (CD45RO+ memory $\mathrm{T}$ cells) by engaging Fc $\gamma \mathrm{RI}$ and Fc $\gamma$ RIII immunoglobulin receptors [2]. Alefacept has been approved by the FDA for treatment of moderate to severe chronic plaque psoriasis in the USA and very recently also in Israel and Switzerland. Due to its dual mechanism of action that results in inhibition of $\mathrm{T}$ cell activation and selective reduction of memory $\mathrm{T}$ cells, the CD4+ cell count has to be regularly monitored, i.e. weekly. Because of the long experience with alefacept by both clinical trials and medical use far from studies, excepting $T$ cell counts no important changes in laboratory values, vital signs and physical examinations were observed [2]. Therefore, alefacept seems to be ideally suited for the long-term treatment of psoriasis. Here, we will present a case after 1 treatment course of 12 weeks with alefacept resulting in long duration of remission as a meaningful measure in psoriasis management.

\section{Case Report}

A 64-year-old female overweight Caucasian with a positive family history for psoriasis had been suffering from chronic plaque-type psoriasis since 1995. Several conventional treatment modalities including UVB at $311 \mathrm{~nm}$ were applied, but induced generally only short remissions. In May 2003, she presented with moderate plaque psoriasis involving the trunk, lower extremities and elbows as well as nail stippling and thick hyperkeratotic scalp lesions. The body surface area (BSA) was about 20\%, the physician global assessment (PGA) was moderate to severe and the psoriasis area severity index (PASI) amounted to 18. Using the visual analogue scale (VAS) from number 0 to 10 , the patient herself estimated to have a disease activity of 9 indicating severe psoriasis. Because quality of life was indeed markedly decreased and feelings of the patient were frustrating, a therapy with alefacept was initiated. According to the treatment recommendation, alefacept was applied at a dose of $15 \mathrm{mg}$ weekly intramuscularly for 12 weeks. Topical treatment with calcipotriene twice daily was continued during alefacept therapy for a total of 6 weeks; after that, only the use of emollients was indicated. At the subsequent weekly visits, physical examination, PASI, BSA, VAS, PGA and laboratory findings, especially CD4+ lymphocyte counts, were assessed. During the 12 weeks of active treatment, a slowly but incremental improvement of skin condition was achieved, resulting in a BSA of $8 \%$ and a PASI of 5.9 after 7 weeks of treatment. Finally, after 12 weeks, a remarkable improvement resulted in a BSA of $2 \%$ and a PASI of 1.0 (fig. 1). The plaques disappeared leaving only mild erythema. At this time, the patient assessed her disease using the VAS as 0 . No application site reactions, relevant changing of lymphocyte count or any other adverse events were observed. After the active treatment period of 3 months, a follow-up period was accomplished. In this postdosing phase, the psoriasis cleared within 2 weeks. There was therefore no longer any necessity for any topical therapy. After a 12-week follow-up, the next subsequent 12-week treatment course was planned but not initiated due to the patient's good skin condition. One year after the end of the active treatment course of alefacept, the skin is still almost clear (BSA: 3\%, PASI: 2.0, PGA almost clear, VAS: 0). In the entire postdosing period, no unwanted side effects were noted. A further follow-up will be done.

\section{Discussion}

For the treatment of psoriasis there are new biologic agents like alefacept, efalizumab and TNF- $\alpha$ antagonists available. Here, we take advantage of our long-lasting experience with alefacept in the therapy of psoriasis. Like other protein-based biologic agents, alefacept has to be applied generally by the parenteral route (e.g. 7.5 $\mathrm{mg}$ intravenously or $15 \mathrm{mg}$ intramuscularly over 12 weeks followed by a 12 -week follow-up). The large pivotal clinical trials reveal 


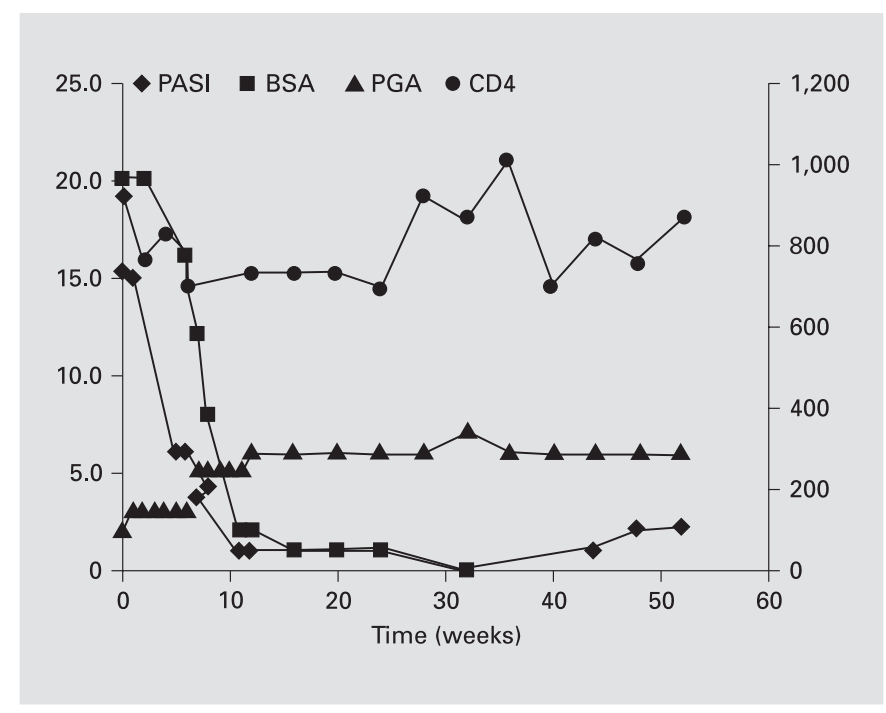

Fig. 1. PASI (score points), BSA (\%), PGA (score points) and CD4+ cells (cells/ $\mu \mathrm{l}$ ) before, during and after alefacept therapy.

overall response rates after 1 intravenous dosing course of 12 weeks of $56 \%$ ( $\geq$ PASI 50$)$ and of $28 \%$ ( $\geq$ PASI 75$)$ that increase in the second course to $71 \%$ ( $\geq$ PASI 50 ) and $40 \%$ ( $\geq$ PASI 75 ), respectively. The corresponding PASI score of a placebo group dropped behind to $24 \%$ ( $\geq$ PASI 50 ) and $8 \%$ ( $\geq$ PASI 75 ) [3]. Similar results could be consistently achieved by the phase III study of $15 \mathrm{mg}$ i.m. once weekly $[4,5]$. As a matter of experience, alefacept is to be considered as a slowly acting biologic agent with incremental effectiveness of 2 or more treatment cycles. However, the fusion protein is characterized essentially by a good tolerability and its safety. The adverse event profile demonstrated by clinical studies reveals no statistically significant differences to placebo. Alefacept's mechanism of action, management of treatment and adverse reaction profile are well documented. Very recently, additional first evidence could be provided that a reduced biweekly monitoring schedule for CD4+ T cells is not associated with an increased risk from alefacept treatment. Although combination therapy was not the primary reason for developing alefacept, preliminary data suggest that the immune modulator might be safely administered in combination with other conventional psoriasis therapies aiming at a further improvement like cyclosporine, systemic retinoids and others.

Much interest has been focused on the determination of the response duration of alefacept therapy after stopping therapy [2, 3, $5,6]$. These data have clearly demonstrated a statistically median duration of approximately 6-7 months if defined as the time that patients maintained a $\geq 50 \%$ reduction from baseline PASI for those patients who achieved $a \geq 75 \%$ reduction from baseline PASI at any time during or after treatment. The rationale for the longlasting remission effect of alefacept is chiefly attributed to the inhibition of $\mathrm{T}$ cell activation and proliferation as well as apoptosis of those $\mathrm{T}$ cells expressing high levels of CD2 (e.g. activated $\mathrm{CD} 4+\mathrm{CD} 45 \mathrm{RO}+, \mathrm{CD} 8+\mathrm{CD} 45 \mathrm{RO}+$ cells) [6]. Thus, as a rule the response to alefacept is durable in most patients. Because in our patient the duration of remission indeed amounted to approximately over 1 year, this observation indicates obviously existing subsets of patients suffering from a chronic stable type. To obtain a more precise understanding of alefacept's action in terms of duration of remission, direct examination of different responders has yet to be carefully made.

\section{References}

1 Ellis CN, Krueger G: Treatment of chronic plaque psoriasis by selective targeting of memory effector T lymphocytes. N Engl J Med 2001;345: 248-255.

2 Krueger GG, Callis KP: Development and use of alefacept to treat psoriasis. J Am Acad Dermatol 2003;49(suppl 2):S87-S97.

3 Krueger GG, Papp KA, Stough DB, Loven KH, Gulliver WP, Ellis CN: A randomized, double-blind, placebo-controlled phase III study evaluating efficacy and tolerability of 2 courses of alefacept in patients with chronic plaque psoriasis. J Am Acad Dermatol 2002;47:821-833.

4 Lebwohl M, Christophers E, Langley R, Ortonne JP, Roberts J, Griffiths CE, Alefacept Clinical Study Group: An international, randomized, double-blind, placebo-controlled phase 3 trial of intramuscular alefacept in patients with chronic plaque psoriasis. Arch Dermatol 2003;139:719727.

5 Gordon KB, Langley RG: Remittive effects of intramuscular alefacept in psoriasis. J Drugs Dermatol 2003;2:624-628.

6 Gordon KB, Vaishnaw AK, O'Gorman J, Haney J, Menter A, Alefacept Clinical Study Group: Treatment of psoriasis with alefacept: Correlation of clinical improvement with reductions of memory T-cell counts. Arch Dermatol 2003;139:1563-1570.

Gottfried Wozel, MD, Department of Dermatology University Hospital Carl Gustav Carus, Technical University Dresden Fetscherstrasse 74, DE-01307 Dresden (Germany) Tel. +49 3514583860, Fax +49 3514585326

E-Mail bluemlei@rcs.urz.tu-dresden.de 